\title{
Time of nitrogen supply in yield, industrial and chemical quality of oat grains
}

\author{
Adriana R. Kraisig ${ }^{1}$, José A. G. da Silva², Ivan R. Carvalho², Ângela T. W. De Mamann², \\ Janiele S. Corso² \& Leonardo Norbert ${ }^{2}$
} ${ }^{1}$ Universidade Regional do Noroeste do Estado do Rio Grande do Sul/Departamento de Ciências Exatas e Engenharias. Ijuí, RS, Brasil. E-mail:
maryshelei@yahoo.com.br (Corresponding author) - ORCID: 0000-0002-5495-7700
${ }^{2}$ Universidade Regional do Noroeste do Estado do Rio Grande do Sul/Departamento de Estudos Agrários. Ijuí, RS, Brasil. E-mail: jagsfaem@yahoo.com.br -
ORCID: 0000-0002-9335-2421; carvalho.irc@gmail.com - ORCID: 0000-0001-7947-4900; janielecorso@outlook.com - ORCID: 0000-0001-7077-2602;
norbert.leonardo6@gmail.com - ORCID: 0000-0001-9005-515X
${ }^{3}$ Instituto Federal de Educação, Ciência e Tecnologia do Rio Grande do Sul. Ibirubá, RS, Brasil. E-mail: angela.mamann@ibiruba.ifrs.edu.br - ORCID:
0000-0002-3650-9007

\begin{abstract}
The timing of nitrogen application in oats can improve the efficiency of use of the nutrient and the expression of productivity and quality of grains. The objective of the study was to indicate the best time of application of nitrogen in oats, considering different conditions of nitrogen dose in the sowing/topdressing in the expression of productivity and the effects on the indicators of industrial and chemical quality of grains, considering the main succession systems of cereal cultivation in Brazil. The experiment was conducted in 2018, in Augusto Pestana, RS, Brazil. The design was randomized blocks with four repetitions, in a $3 \times 4$ factorial scheme, with three doses of nitrogen at sowing $\left(0,30\right.$ and $\left.60 \mathrm{~kg} \mathrm{ha}^{-1}\right)$, changing the topdressing dose by the total supply of 70 and $100 \mathrm{~kg} \mathrm{ha}^{-1}$ in succession system soybean/oats and corn/oats, respectively, with the timings of supply in topdressing at $0,10,30$ and 60 days after emergence. The total doses were defined looking for grain yield expectations of $4000 \mathrm{~kg} \mathrm{ha}^{-1}$. In the management of nitrogen in oats, the absence of the nutrient at sowing and application of the total dose in topdressing around 30 days after emergence provides advantageous results, improving productivity and indicators of industrial and chemical quality of grains.
\end{abstract}

Key words: Avena sativa, N-sowing, N-topdressing

\section{Época de fornecimento do nitrogênio na produtividade, qualidade industrial e química de grãos de aveia}

\begin{abstract}
RESUMO: O momento de aplicação de nitrogênio em aveia pode melhorar a eficiência de aproveitamento do nutriente e a expressão da produtividade e qualidade de grãos. $\mathrm{O}$ objetivo do estudo foi indicar a melhor época de aplicação de nitrogênio em aveia, considerando diferentes condições de fornecimento de doses de nitrogênio na semeadura e em cobertura na produtividade e nos indicadores da qualidade industrial e química de grãos, considerando dois sistemas de sucessão de cultivo do cereal no Brasil. O experimento foi conduzido no ano de 2018, em Augusto Pestana, RS, Brasil. O delineamento foi o de blocos casualizados com quatro repetições, em esquema fatorial $3 \times 4$, para três doses de nitrogênio na semeadura $\left(0,30\right.$ e $\left.60 \mathrm{~kg} \mathrm{ha}^{-1}\right)$ alterando a dose em cobertura pelo total fornecido de 70 e $100 \mathrm{~kg} \mathrm{ha}^{-1} \mathrm{em}$ sistema soja/aveia e milho/aveia, respectivamente. $O$ fornecimento do nutriente em cobertura foi em quatro épocas $(0,10,30$ e 60 dias) após a emergência da aveia. A ausência do nutriente na semeadura e aplicação da dose total em cobertura ao redor de 30 dias após emergência proporciona resultados vantajosos, melhorando a produtividade e indicadores da qualidade industrial e química dos grãos.
\end{abstract}

Palavras-chave: Avena sativa, N-semeadura, N-cobertura 


\section{INTRODUCTION}

In a globalized market, achieving self-sufficiency and competitiveness in Brazilian oats is decisive. Therefore, the aim must be at the development of more productive, tolerant and efficient cultivars in the use of light and nutrients. Aside from the meteorological aspects, nitrogen management is essential to increase the productivity and quality of grains (Mantai et al., 2015; Silva et al., 2016).

The definition of the $\mathrm{N}$-fertilizer dose in oats is derived from the organic matter content of the soil, the previous crop and the grain yield expectation (Mantai et al., 2016; Marolli et al., 2017). On the other hand, the most propitious time for topdressing falls only on the phenology of the plant linked to the period of greatest lack of nutrients in the formation of production components (Bredemeier et al., 2013; Mantai et al., 2015). The technical indications for wheat and oats in Brazil recommend as fertilization season, the period between the beginning of tillering (stage $\mathrm{V}_{3}$ ) and the beginning of elongation (stage $\mathrm{V}_{6}$ ), an interval of around 30 to 60 days after plant emergence (Arenhardt et al., 2015; Marolli et al., 2017). These same authors reported that the timing of nitrogen fertilization should also take into account the predecessor crop, due to the different dynamics of biomass decomposition in the release of N-residual. Therefore, apart from the most favorable conditions of soil moisture, other factors should be explored to size the most adjusted season, which would allow greater use of the nutrient for the expression of productivity and the attributes of interest to the processing industry and the consumer market.

The objective of this study was to indicate the best time for nitrogen application in oats, considering different conditions of nitrogen dose supply in sowing and topdressing in productivity and in the indicators of industrial and chemical quality of grains, considering two succession systems of cereal cultivation in Brazil.

\section{Material ANd Methods}

The study was developed under field conditions in the agricultural year 2018 in Augusto Pestana, RS, Brazil (28 26' 30” S, $54^{\circ} 0^{\prime} 58^{\prime \prime} \mathrm{O}$ and altitude of $400 \mathrm{~m}$ ). The soil of the experimental area is classified as Oxisol, the climate of the region, according to the Köppen classification, is of the Cfa type, with hot summer without dry season (Alvares et al., 2013). The air temperature $\left({ }^{\circ} \mathrm{C}\right)$ and rainfall $(\mathrm{mm})$ information for analysis of the meteorological conditions of the agricultural year, were obtained by the Total Automatic Station installed $500 \mathrm{~m}$ from the experiment.

Twenty days before sowing, soil analysis was carried out and the following chemical characteristics were determined: soybean/oat system $\left(\mathrm{pH}=6.2 ; \mathrm{P}=33.9 \mathrm{mg} \mathrm{dm}^{-3} ; \mathrm{K}=200 \mathrm{mg} \mathrm{dm}^{-3}\right.$; $\mathrm{MO}=3.0 \% ; \mathrm{Al}=0 \mathrm{cmol}_{\mathrm{c}} \mathrm{dm}^{-3} ; \mathrm{Ca}=6.5 \mathrm{cmol}_{\mathrm{c}} \mathrm{dm}^{-3}$ and $\mathrm{Mg}=$ $\left.2.5 \mathrm{cmol} \mathrm{dm}^{-3}\right)$ corn/oat system $\left(\mathrm{pH}=6.5 ; \mathrm{P}=34.4 \mathrm{mg} \mathrm{dm}^{-3} ; \mathrm{K}=\right.$ $262 \mathrm{mg} \mathrm{dm}{ }^{-3} ; \mathrm{MO}=2.9 \% ; \mathrm{Al}=0 \mathrm{cmol}_{\mathrm{c}} \mathrm{dm}^{-3} ; \mathrm{Ca}=6.6 \mathrm{cmol}_{\mathrm{c}} \mathrm{dm}^{-3}$ and $\mathrm{Mg}=3.4 \mathrm{cmol}_{c} \mathrm{dm}^{-3}$ ). The sowing was carried out in the third week of June with seeder-fertilizer in the composition of the plot with 5 lines of $5 \mathrm{~m}$ in length and spacing between lines of $0.20 \mathrm{~m}$, forming the experimental unit of $5 \mathrm{~m}^{2}$. The population density used was 400 viable seeds $\mathrm{m}^{-2}$. During the execution of the study, applications of tebuconazole fungicide were carried out at a dose of $0.75 \mathrm{~L} \mathrm{ha}^{-1}$. Weed control was carried out with metsulfuron-methyl herbicide at a dose of 4 $\mathrm{g} \mathrm{ha}^{-1}$. In the sowing, 45 and $30 \mathrm{~kg} \mathrm{ha}^{-1}$ of $\mathrm{P}_{2} \mathrm{O}_{5}$ and $\mathrm{K}_{2} \mathrm{O}$ were applied, respectively, based on the contents of $\mathrm{P}$ and $\mathrm{K}$ in the soil and with expected grain productivity of $4 \mathrm{tha}^{-1}$.

In each cultivation system (soybean/oats; corn/oats), the experiments were conducted in a randomized block design with four repetitions in a $3 \times 4$ factorial scheme, using three doses of nitrogen at sowing $\left(0,30\right.$ and $\left.60 \mathrm{~kg} \mathrm{ha}^{-1}\right)$. The total topdressing dose supplied was changed to 70 and $100 \mathrm{~kg} \mathrm{ha}^{-1}$ in the soybean/oat and corn/oat systems, respectively, with an expected grain yield of $4000 \mathrm{~kg} \mathrm{ha}^{-1}$; topdressing was supplied in four application times $(0,10,30$ and 60 days after emergence), totaling 48 experimental units per succession system.

In the study, variables related to productivity, industrial quality and chemical composition of grains were evaluated. Grain productivity ( $\mathrm{PG}, \mathrm{kg} \mathrm{ha}^{-1}$ ) was obtained by cutting three central lines of each plot during the harvest maturity period, grain moisture was close to $22 \%$. They were tracked with a stationary harvester and later directed to the laboratory to correct grain moisture to $13 \%$. The mass of 1000 grains (MMG, g) was determined by counting 250 grains and weighing on a precision scale, subsequently multiplied by four. The hectoliter mass $\left(\mathrm{MH}, \mathrm{kg} \mathrm{hL}^{-1}\right)$ was obtained by the mass of grains from a cube of known volume of $250 \mathrm{~cm}^{3}$, and converted to $\mathrm{kg} \mathrm{hL}^{-1}$. The number of grains larger than two millimeters (NG $>2$ $\mathrm{mm}, \mathrm{n}$ ) was obtained by counting 100 grains, which were placed in a $2 \mathrm{~mm}$ mesh sieve and those that were retained were counted. The dehulling index (ID, $\mathrm{g} \mathrm{g}^{-1}$ ) was determined by the ratio between the karyopse mass of 50 grains greater than $2 \mathrm{~mm}$ and its grain mass. The industrial productivity (PI, $\mathrm{kg} \mathrm{ha}^{-1}$ ) was obtained by the product of grain productivity with the number of grains greater than $2 \mathrm{~mm}$ and the dehulling index (PI= PG $x$ NG $>2 \mathrm{~mm} \times \mathrm{ID})$. The concentrations of crude protein $\left(\mathrm{PB}, \mathrm{g} \mathrm{kg}^{-1}\right)$, crude fiber $\left(\mathrm{FB}, \mathrm{g} \mathrm{kg}^{-1}\right)$ and starch (AM, $\mathrm{g} \mathrm{kg}^{-1}$ ) were determined in samples of unhulled grains, using the NIR spectrometer (Near Infrared Reflectance), through near infrared spectrophotometry - NIRS (Perten brand, model Diode Array DA7200).

Analysis of variance was performed to detect the significance of the main and interaction effects. Based on this information, Scott and Knott's means comparison test was performed at $\mathrm{p} \leq 0.05$. Afterwards, the quadratic equation adjustment $\left(\mathrm{Y}=\mathrm{b}_{0} \pm \mathrm{b}_{1} \mathrm{x} \pm \mathrm{b}_{2} \mathrm{x}^{2}\right)$ was performed to estimate the ideal day of supply of the nutrient by topdressing.

\section{Results ANd Discussion}

In Figure 1, the meteorological conditions in the oat cultivation cycle were favorable for the supply of nutrients 10 and 30 days after emergence, with the presence of moisture in the soil due to rains that occurred in days prior to fertilization and milder air temperatures. In these periods, the most significant volumes of precipitation occurred one week after 


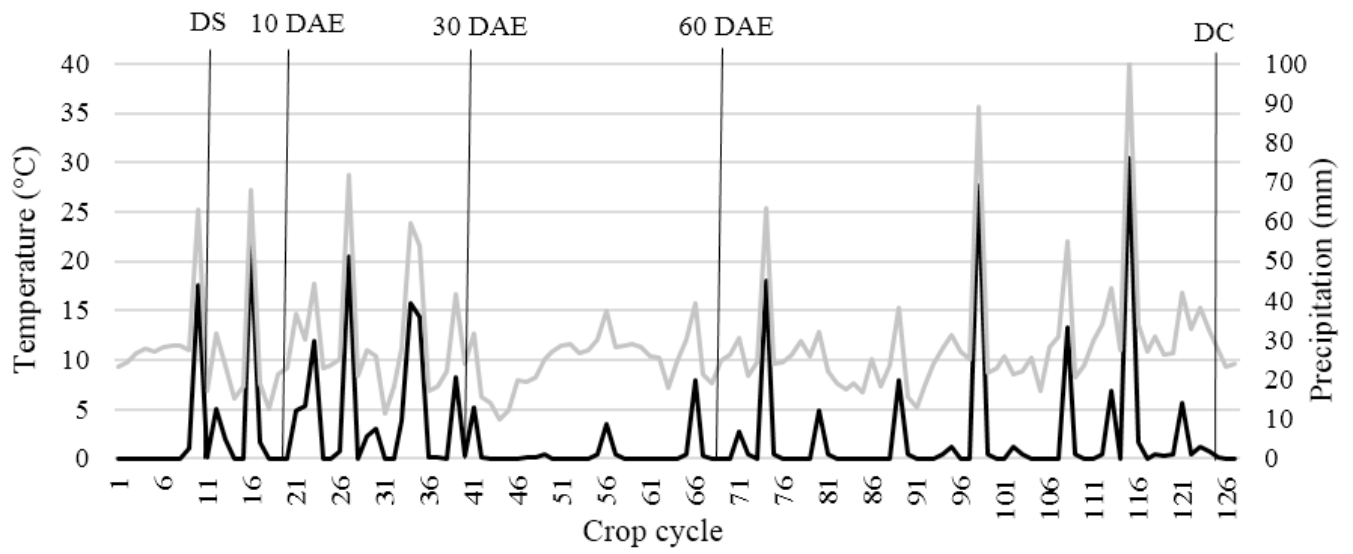

- Precipitation (mm) Maximum daily temperature $\left({ }^{\circ} \mathrm{C}\right)$

DS - Date of sowing (09/06); DC - Date of harvest; DAE - Days after the emergence; Data obtained from the weather station located at the Instituto Regional de Desenvolvimento Rural

Figure 1. Data of rainfall and maximum daily temperature during the oat cultivation cycle, in 2015

fertilization, ensuring nitrogen utilization by the plant with less losses by leaching.

In the supply at 60 days after emergence, low soil moisture was observed, due to the long period with reduced precipitation between 43 and 65 days after emergence. In addition, temperatures were higher at the time of management compared to other seasons, which possibly favored greater nitrogen losses by volatilization. It is noteworthy that results with conditions of water restriction in this season have been happening more frequently in recent years, according to records of previous studies.

Rainfall stands out as one of the main factors responsible for variations in agricultural productivity. Prior knowledge of precipitation conditions may indicate forms of management that ensure the success of the activity (Arf et al., 2012; Arenhardt et al., 2015). In winter cereals, rainfall without large volumes, which favors adequate soil moisture and is well distributed throughout the cultivation cycle, characterizes an environment favorable to nitrogen management and greater expression of productivity (Castro et al., 2012; Souza et al., 2013).

In addition to precipitation, the air temperature also acts with a strong action on the nitrogen utilization dynamics and expression of productivity. Temperature acts as a catalyst for biological processes, which is why plants require a minimum and maximum temperature for normal physiological activities (Tonin et al., 2014; Marolli et al., 2017). In cereals, such as oats and wheat, the milder temperatures and quality of solar radiation throughout the day, favor the tillering and filling of grains, with direct effects on productivity (Castro et al., 2012; Arenhardt et al., 2015). In nitrogen management, the occurrence of high volume and/or intensity of rainfall, soon after fertilization, reduces plant efficiency due to lack of oxygenation and generates nutrient loss by leaching (Ercoli et al., 2013; Scremin et al., 2017). The same authors stated that high temperatures also reduce fertilization efficiency due to volatilization losses.

In Table 1, from the analysis of variance in the soybean/oat system, the times and doses of nitrogen affected grain yield,

Table 1. Analysis of variance of the characters of grain yield, industry and chemical quality by the time of nitrogen supply at sowing /topdressing

\begin{tabular}{|c|c|c|c|c|c|c|c|c|c|c|}
\hline \multirow{2}{*}{$\begin{array}{c}\text { Source } \\
\text { of variation }\end{array}$} & \multirow{2}{*}{ GL } & \multicolumn{9}{|c|}{ Mean square } \\
\hline & & $P G$ & $\mathrm{MH}$ & MMG & $\mathrm{NG}>2 \mathrm{~mm}$ & ID & PI & PB & FB & AM \\
\hline & & \multicolumn{9}{|c|}{ Soybean/oat system } \\
\hline Block & 3 & 41078 & 6,75 & 0.23 & 17.58 & 0.0003 & 12170 & 17.27 & 12.07 & 38.74 \\
\hline Time-N (EN) & 3 & $2478216^{*}$ & $71.91^{*}$ & 0.55 & 71.25 & $0.0061^{*}$ & $708658 *$ & $73.50^{*}$ & 10.02 & 130.07 \\
\hline Dose-N (DN) & 2 & $322200^{*}$ & $70.06^{*}$ & 0.89 & 48.52 & 0.0038 & 269204* & $50.27^{\star}$ & 12.33 & 80.14 \\
\hline EN $\times$ DN & 6 & $245137^{*}$ & $16.89 *$ & 0.11 & 28.02 & 0.0033 & $55661 *$ & $23.43^{*}$ & 12.16 & 126.60 \\
\hline Error & 33 & 41598 & 1.02 & 1.19 & 12.01 & 0.0011 & 15571 & 4.55 & 5.16 & 28.94 \\
\hline Total & 47 & & & & & & & & & \\
\hline Overall mean & - & 2763 & 46.37 & 24.69 & 57.79 & 0.69 & 1120 & 112.58 & 125.10 & 444.27 \\
\hline CV (\%) & - & 17.37 & 7.18 & 6.41 & 9.99 & 7.80 & 11.13 & 3.89 & 3.81 & 4.21 \\
\hline \multicolumn{11}{|c|}{ Corn/oat system } \\
\hline Block & 3 & 25594 & 0.24 & 0.55 & 10.83 & 0.0012 & 29096 & 10.07 & 16.36 & 12.75 \\
\hline Time-N (EN) & 3 & $2610173^{*}$ & $36.40^{*}$ & 2.17 & 64.50 & 0.0022 & $389273^{*}$ & $259.00 *$ & 5.00 & 46.90 \\
\hline Dose-N (DN) & 2 & $1424596^{\star}$ & 4.75 & 7.23 & 29.31 & 0.0037 & $426430 \star$ & $16.58^{\star}$ & 9.02 & 22.64 \\
\hline $\mathrm{EN} \times \mathrm{DN}$ & 6 & $515952^{*}$ & $12.00^{*}$ & 1.74 & 19.72 & 0.0031 & $96418 *$ & $62.83^{*}$ & 8.21 & 91.97 \\
\hline Error & 33 & 31291 & 1.57 & 0.91 & 28.96 & 0.001 & 28212 & 5.28 & 6.37 & 43.44 \\
\hline \multirow[t]{2}{*}{ Total } & 47 & & & & & & & & & \\
\hline & & $\left(\mathrm{kg} \mathrm{ha}^{-1}\right)$ & $\left(\mathrm{kg} \mathrm{hL}^{-1}\right)$ & (g) & (n) & $\left(\mathrm{g} \mathrm{g}^{-1}\right)$ & $\left(\mathrm{kg} \mathrm{ha}^{-1}\right)$ & $\left(\mathrm{g} \mathrm{kg}^{-1}\right)$ & $\left(\mathrm{g} \mathrm{kg}^{-1}\right)$ & $\left(\mathrm{g} \mathrm{kg}^{-1}\right)$ \\
\hline Overall mean & - & 2991 & 43.43 & 23.40 & 57.75 & 0.65 & 1138 & 108.14 & 129.95 & 440.54 \\
\hline CV (\%) & & 15.91 & 7.89 & 6.07 & 9.32 & 8.10 & 13.75 & 5.12 & 4.94 & 5.49 \\
\hline
\end{tabular}

* - Significant at $\mathrm{p} \leq 0.05$ by F test; GL - Degrees of freedom; CV - Coefficient of variation; EN -Time of nitrogen application (days after emergence); DN - Nitrogen dose at sowing/ topdressing $\left(\mathrm{kg} \mathrm{ha}^{-1}\right)$; PG - Grain productivity; MH - Hectoliter mass; MMG - Mass of one thousand grains; NG > 2 mm - Number of grains larger than 2 mm; ID - Dehulling Index; PI - Industrial productivity; PB - Crude protein; FB - Crude fiber; AM - Starch 
hectoliter mass, industrial productivity and crude protein. The dehulling index was only changed by the times of nitrogen supply in topdressing. In the corn/oat system the time and nitrogen dose also altered the same variables indicated in the soybean/oat system, except for hectoliter mass that was not modified by nitrogen dose. In this condition, the dehulling index did not show differences by the time of supply, differently from what happened in the soybean/oat system. Regardless of the succession system, the time and nitrogen dose interaction was confirmed on grain yield, hectoliter mass, industrial productivity and crude protein, indicating the need to unfold this interaction by analyzing the simplified effects.

In Table 2, in the soybean/oat system, grain yields showed superior results with the absence of nitrogen at sowing and the total topdressing dose of $70 \mathrm{~kg} \mathrm{ha}^{-1}$, and also in the combination of $30 \mathrm{~kg} \mathrm{ha}^{-1}$ at sowing and $40 \mathrm{~kg} \mathrm{ha}^{-1}$ in topdressing, when supplied 30 days after emergence. The combinations mentioned in the sowing and topdressing also expressed the best results on the hectoliter mass, however, with an indication of the time of fertilization both at 10 and 30 days after emergence.

Table 2. Means of indicators of productivity and grain quality in times of nitrogen supply at sowing/topdressing in the soybean/oat system

\begin{tabular}{|c|c|c|c|c|c|}
\hline $\begin{array}{l}\text { N-Dose at } \\
\text { sowing }\end{array}$ & $\begin{array}{l}\text { N-Dose at } \\
\text { topdressing }\end{array}$ & \multicolumn{4}{|c|}{ N-Time (days) } \\
\hline \multicolumn{2}{|c|}{$\left(k_{g} h^{-1}\right)$} & $\overline{0}$ & 10 & 30 & 60 \\
\hline & & \multicolumn{4}{|c|}{ Grain productivity $\left(\mathrm{kg} \mathrm{ha}^{-1}\right)$} \\
\hline 0 & 70 & $2315 \mathrm{Cb}$ & $2829 \mathrm{Ba}$ & $3659 \mathrm{Aa}$ & $2354 \mathrm{Cb}$ \\
\hline 30 & 40 & $2079 \mathrm{Cb}$ & $2825 \mathrm{Ba}$ & $3392 \mathrm{Aa}$ & $2191 \mathrm{Cb}$ \\
\hline \multirow[t]{2}{*}{60} & 10 & $1709 \mathrm{Ba}$ & $2248 \mathrm{Ba}$ & $2962 \mathrm{Ab}$ & $1860 \mathrm{Ba}$ \\
\hline & & \multicolumn{4}{|c|}{ Hectoliter mass $\left(\mathrm{kg} \mathrm{hL}^{-1}\right)$} \\
\hline 0 & 70 & $44 \mathrm{Bb}$ & $49 \mathrm{Aa}$ & $50 \mathrm{Aa}$ & $42 \mathrm{Ca}$ \\
\hline 30 & 40 & $45 \mathrm{Bb}$ & $49 \mathrm{Aa}$ & $48 \mathrm{Aa}$ & $43 \mathrm{Ca}$ \\
\hline \multirow[t]{2}{*}{60} & 10 & $48 \mathrm{Aa}$ & $45 \mathrm{Cb}$ & $47 \mathrm{Ba}$ & $44 \mathrm{Da}$ \\
\hline & & \multicolumn{4}{|c|}{ Mass of one thousand grains $(\mathrm{g})$} \\
\hline 0 & 70 & $24 \mathrm{Aa}$ & $26 \mathrm{Aa}$ & $24 \mathrm{Aa}$ & $25 \mathrm{Aa}$ \\
\hline 30 & 40 & $23 \mathrm{Aa}$ & $23 \mathrm{Aa}$ & $25 \mathrm{Aa}$ & $24 \mathrm{Aa}$ \\
\hline \multirow[t]{2}{*}{60} & 10 & $25 \mathrm{Aa}$ & $25 \mathrm{Aa}$ & $24 \mathrm{Aa}$ & $24 \mathrm{Aa}$ \\
\hline & & \multicolumn{4}{|c|}{ Number of grains $>2 \mathrm{~mm}(\mathrm{n})$} \\
\hline 0 & 70 & $57 \mathrm{Aa}$ & $57 \mathrm{Aa}$ & $61 \mathrm{Aa}$ & $60 \mathrm{Aa}$ \\
\hline 30 & 40 & $53 \mathrm{Aa}$ & $52 \mathrm{Aa}$ & $57 \mathrm{Aa}$ & $53 \mathrm{Aa}$ \\
\hline \multirow[t]{2}{*}{60} & 10 & $52 \mathrm{Aa}$ & $59 \mathrm{Aa}$ & $59 \mathrm{Aa}$ & $57 \mathrm{Aa}$ \\
\hline & & \multicolumn{4}{|c|}{ Dehulling Index $\left(\mathrm{g} \mathrm{g}^{-1}\right)$} \\
\hline 0 & 70 & $0.69 \mathrm{Ba}$ & $0.72 \mathrm{Aa}$ & $0.74 \mathrm{Aa}$ & $0.67 \mathrm{Ba}$ \\
\hline 30 & 40 & $0.71 \mathrm{Aa}$ & $0.73 \mathrm{Aa}$ & $0.72 \mathrm{Aa}$ & $0.65 \mathrm{Ba}$ \\
\hline \multirow[t]{2}{*}{60} & 10 & $0.70 \mathrm{Aa}$ & $0.71 \mathrm{Aa}$ & $0.69 \mathrm{Aa}$ & $0.67 \mathrm{Aa}$ \\
\hline & & \multicolumn{4}{|c|}{ Industrial productivity $\left(\mathrm{kg} \mathrm{ha}^{-1}\right)$} \\
\hline 0 & 70 & $914 \mathrm{Ca}$ & $1316 \mathrm{Ba}$ & $1609 \mathrm{Aa}$ & $1051 \mathrm{Ca}$ \\
\hline 30 & 40 & $792 \mathrm{Ba}$ & $939 \mathrm{Bb}$ & $1413 \mathrm{Ab}$ & $754 \mathrm{Bb}$ \\
\hline \multirow[t]{2}{*}{60} & 10 & $662 \mathrm{Ca}$ & $941 \mathrm{Bb}$ & $1205 \mathrm{Ab}$ & $735 \mathrm{Ca}$ \\
\hline & & \multicolumn{4}{|c|}{ Crude protein $\left(\mathrm{g} \mathrm{kg}^{-1}\right)$} \\
\hline 0 & 70 & $104 \mathrm{Ba}$ & $106 \mathrm{Ba}$ & $109 \mathrm{Ba}$ & $116 \mathrm{Aa}$ \\
\hline 30 & 40 & $104 \mathrm{Ba}$ & $105 \mathrm{Ba}$ & $110 \mathrm{Ba}$ & $117 \mathrm{Aa}$ \\
\hline \multirow[t]{2}{*}{60} & 10 & $96 \mathrm{Ba}$ & $99 \mathrm{Ba}$ & $111 \mathrm{Aa}$ & $113 \mathrm{Aa}$ \\
\hline & & \multicolumn{4}{|c|}{ Crude fibre $\left(\mathrm{g} \mathrm{kg}^{-1}\right)$} \\
\hline 0 & 70 & $125 \mathrm{Aa}$ & $125 \mathrm{Aa}$ & $126 \mathrm{Aa}$ & $121 \mathrm{Aa}$ \\
\hline 30 & 40 & $124 \mathrm{Aa}$ & $123 \mathrm{Aa}$ & $127 \mathrm{Aa}$ & $120 \mathrm{Aa}$ \\
\hline \multirow[t]{2}{*}{60} & 10 & $121 \mathrm{Aa}$ & $126 \mathrm{Aa}$ & $123 \mathrm{Aa}$ & $125 \mathrm{Aa}$ \\
\hline & & \multicolumn{4}{|c|}{ Starch $\left(\mathrm{g} \mathrm{kg}^{-1}\right)$} \\
\hline 0 & 70 & $443 \mathrm{Aa}$ & $446 \mathrm{Aa}$ & $442 \mathrm{Aa}$ & $448 \mathrm{Aa}$ \\
\hline 30 & 40 & $442 \mathrm{Aa}$ & $442 \mathrm{Aa}$ & $449 \mathrm{Aa}$ & $446 \mathrm{Aa}$ \\
\hline 60 & 10 & $441 \mathrm{Aa}$ & $441 \mathrm{Aa}$ & $443 \mathrm{Aa}$ & $449 \mathrm{Aa}$ \\
\hline
\end{tabular}

Means followed by the same lowercase letters in the column and uppercase letters in the lines do not differ statistically from each other at $\mathrm{p} \leq 0.05$ by the Scott and Knott's test
In the dehulling index, the component of interest to the industry which is the highest values of expression, do not depend on the nitrogen dose in fertilization; however, the time of supply is more adjusted at 10 and 30 days after emergence. In industrial productivity, the combination of absence of nitrogen in sowing with total supply in topdressing applied at 30 days after emergence was decisive in the increment. In this system, the only component of chemical quality that showed alteration was the protein content in the grains, with more expressive results when applied at 60 days after emergence, regardless of the nitrogen dose at sowing.

In Table 3, in the corn/oat system, the combination of absence of nitrogen at sowing with the total topdressing dose of $100 \mathrm{~kg} \mathrm{ha}^{-1}$ provided the highest grain yield when applied at 10 and 30 days after emergence. The combination of $30 \mathrm{~kg} \mathrm{ha}^{-1}$ of nitrogen at sowing and $70 \mathrm{~kg} \mathrm{ha}^{-1}$ in topdressing also showed expressive results in grain yield, when supplied 30 days after emergence.

Hectoliter mass showed more expressive values with supply at 10 and 30 days after emergence, regardless of nitrogen dose

Table 3. Means of indicators of grain yield and quality in times of nitrogen supply at sowing /topdressing in the corn/ oat system

\begin{tabular}{|c|c|c|c|c|c|}
\hline $\begin{array}{l}\mathrm{N} \text {-Dose at } \\
\text { sowing }\end{array}$ & $\begin{array}{l}\text { N-Dose at } \\
\text { topdressing }\end{array}$ & \multicolumn{4}{|c|}{ N-Time (days) } \\
\hline \multicolumn{2}{|c|}{$\left(\mathrm{kg} \mathrm{ha}^{-1}\right)$} & $\overline{0}$ & 10 & 30 & 60 \\
\hline & & \multicolumn{4}{|c|}{ Grain productivity $\left(\mathrm{kg} \mathrm{ha}^{-1}\right)$} \\
\hline 0 & 100 & $1793 \mathrm{Cb}$ & $3491 \mathrm{Aa}$ & $3363 \mathrm{Aa}$ & $2754 \mathrm{Ba}$ \\
\hline 30 & 70 & $2287 \mathrm{Ca}$ & $3038 \mathrm{Bb}$ & 3389 Aa & $2441 \mathrm{Cb}$ \\
\hline \multirow[t]{2}{*}{60} & 40 & $1231 \mathrm{Cc}$ & $2288 \mathrm{BC}$ & $2646 \mathrm{Ab}$ & $2170 \mathrm{BC}$ \\
\hline & & \multicolumn{4}{|c|}{ Hectolitre mass $\left(\mathrm{kg} \mathrm{hL}^{-1}\right)$} \\
\hline 0 & 100 & $39 \mathrm{Ba}$ & $44 \mathrm{Aa}$ & $44 \mathrm{Aa}$ & $42 \mathrm{Aa}$ \\
\hline 30 & 70 & $41 \mathrm{Ba}$ & $45 \mathrm{Aa}$ & $46 \mathrm{Aa}$ & $43 \mathrm{Ba}$ \\
\hline \multirow[t]{2}{*}{60} & 40 & $42 \mathrm{Aa}$ & $43 \mathrm{Aa}$ & $45 \mathrm{Aa}$ & $45 \mathrm{Aa}$ \\
\hline & & \multicolumn{4}{|c|}{ Mass of a thousand grains $(\mathrm{g})$} \\
\hline 0 & 100 & $22 \mathrm{Aa}$ & $25 \mathrm{Aa}$ & $24 \mathrm{Aa}$ & $21 \mathrm{Aa}$ \\
\hline 30 & 70 & $21 \mathrm{Aa}$ & $23 \mathrm{Aa}$ & $23 \mathrm{Aa}$ & $21 \mathrm{Aa}$ \\
\hline \multirow[t]{2}{*}{60} & 40 & $23 \mathrm{Aa}$ & $23 \mathrm{Aa}$ & $24 \mathrm{Aa}$ & $23 \mathrm{Aa}$ \\
\hline & & \multicolumn{4}{|c|}{ Number of grains $>2 \mathrm{~mm}(\mathrm{n})$} \\
\hline 0 & 100 & $52 \mathrm{Aa}$ & $55 \mathrm{Aa}$ & $60 \mathrm{Aa}$ & $59 \mathrm{Aa}$ \\
\hline 30 & 70 & $56 \mathrm{Aa}$ & $59 \mathrm{Aa}$ & $53 \mathrm{Aa}$ & $59 \mathrm{Aa}$ \\
\hline \multirow[t]{2}{*}{60} & 40 & $57 \mathrm{Aa}$ & $57 \mathrm{Aa}$ & $56 \mathrm{Aa}$ & $57 \mathrm{Aa}$ \\
\hline & & \multicolumn{4}{|c|}{ Dehulling index $\left(\mathrm{g} \mathrm{g}^{-1}\right)$} \\
\hline 0 & 100 & $0.67 \mathrm{Aa}$ & $0.61 \mathrm{Aa}$ & $0.72 \mathrm{Aa}$ & $0.65 \mathrm{Aa}$ \\
\hline 30 & 70 & $0.67 \mathrm{Aa}$ & $0.61 \mathrm{Aa}$ & $0.64 \mathrm{Aa}$ & $0.63 \mathrm{Aa}$ \\
\hline \multirow[t]{2}{*}{60} & 40 & $0.67 \mathrm{Aa}$ & $0.69 \mathrm{Aa}$ & $0.65 \mathrm{Aa}$ & $0.66 \mathrm{Aa}$ \\
\hline & & \multicolumn{4}{|c|}{ Industrial productvity $\left(\mathrm{kg} \mathrm{ha}^{-1}\right)$} \\
\hline 0 & 100 & $764 \mathrm{Cb}$ & $1199 \mathrm{Ba}$ & $1459 \mathrm{Aa}$ & $895 \mathrm{Cb}$ \\
\hline 30 & 70 & $869 \mathrm{Bb}$ & $1101 \mathrm{Aa}$ & $1164 \mathrm{Aa}$ & $916 \mathrm{Bb}$ \\
\hline \multirow[t]{2}{*}{60} & 40 & $470 \mathrm{Ba}$ & $890 \mathrm{Ab}$ & $963 \mathrm{Aa}$ & $816 \mathrm{Aa}$ \\
\hline & & \multicolumn{4}{|c|}{ Crude protein $\left(\mathrm{g} \mathrm{kg}^{-1}\right)$} \\
\hline 0 & 100 & $98 \mathrm{Ca}$ & $103 \mathrm{Bb}$ & $111 \mathrm{Aa}$ & $116 \mathrm{Aa}$ \\
\hline 30 & 70 & $98 \mathrm{Ca}$ & $100 \mathrm{Bb}$ & $110 \mathrm{Aa}$ & $114 \mathrm{Aa}$ \\
\hline \multirow[t]{2}{*}{60} & 40 & $97 \mathrm{Ca}$ & $97 \mathrm{Ba}$ & $110 \mathrm{Aa}$ & $108 \mathrm{Aa}$ \\
\hline & & \multicolumn{4}{|c|}{ Crude fibre $\left(\mathrm{g} \mathrm{kg}^{-1}\right)$} \\
\hline 0 & 100 & $129 \mathrm{Aa}$ & $128 \mathrm{Aa}$ & $127 \mathrm{Aa}$ & $127 \mathrm{Aa}$ \\
\hline 30 & 70 & $132 \mathrm{Aa}$ & $129 \mathrm{Aa}$ & $128 \mathrm{Aa}$ & $129 \mathrm{Aa}$ \\
\hline \multirow[t]{2}{*}{60} & 40 & $130 \mathrm{Aa}$ & $130 \mathrm{Aa}$ & $129 \mathrm{Aa}$ & $126 \mathrm{Aa}$ \\
\hline & & \multicolumn{4}{|c|}{ Starch $\left(\mathrm{g} \mathrm{kg}^{-1}\right)$} \\
\hline 0 & 100 & $440 \mathrm{Aa}$ & $441 \mathrm{Aa}$ & $442 \mathrm{Aa}$ & $439 \mathrm{Aa}$ \\
\hline 30 & 70 & $434 \mathrm{Aa}$ & $443 \mathrm{Aa}$ & $444 \mathrm{Aa}$ & $435 \mathrm{Aa}$ \\
\hline 60 & 40 & $439 \mathrm{Aa}$ & $442 \mathrm{Aa}$ & $450 \mathrm{Aa}$ & $430 \mathrm{Aa}$ \\
\hline
\end{tabular}

Means followed by the same lowercase letters in the column and uppercase letters in the lines do not differ statistically from each other at $\mathrm{p} \leq 0.05$ by the Scott and Knott's test 
at sowing. In industrial productivity, regardless of the dose at sowing, superior results were obtained when supplied at 30 days after emergence. In the analysis of protein content, the supply of fertilizer at 30 and 60 days after emergence showed more promising results, regardless of the nitrogen dose at sowing.

In Table 4, from the regression equation in the soybean/ oat system, the variables grain yield, hectoliter mass, dehulling index, industrial productivity and crude protein showed significant quadratic behavior, in the combination of absence of nitrogen in sowing with $70 \mathrm{kgha}^{-1}$ of nitrogen in topdressing, depending on the time of nitrogen supply. Thus, the ideal time of supply by topdressing was more efficient at 33 days after emergence in the expression of grain yield. It is noteworthy that the main equation for estimating the ideal time falls on productivity, the variable of greatest economic importance for the farmer. Thus, the estimation of expression of the other variables takes into account the ideal time obtained by productivity by including 33 (days) in the parameter $\mathrm{b}_{\mathrm{i}} \mathrm{x}^{\mathrm{n}}$ of the significant regression equations. Thus, an expression of hectoliter mass was observed with $45.30 \mathrm{~kg} \mathrm{hL}^{-1}$, dehulling index of $0.70 \mathrm{~g} \mathrm{~g}^{-1}$, industrial productivity of $1480 \mathrm{~kg} \mathrm{ha}^{-1}$ and crude protein with $109.80 \mathrm{~g} \mathrm{~kg}^{-1}$.

The combination of $30 \mathrm{~kg} \mathrm{ha}^{-1}$ of nitrogen at sowing with $40 \mathrm{~kg} \mathrm{ha}^{-1}$ in topdressing depending on the time of supply in topdressing, shows significant quadratic behavior for the

Table 4. Regression and estimation of the ideal day of nitrogen supply in the indicators of productivity and grain quality in the soybean/oat system

\begin{tabular}{|c|c|c|c|c|c|}
\hline Variable & Equation & $\begin{array}{l}\text { CV } \\
(\%)\end{array}$ & $\mathbf{R}^{2}$ & $\begin{array}{l}\text { Ideal N-time } \\
\text { (days) }\end{array}$ & $\begin{array}{c}\mathbf{Y} \\
\text { (estimated) }\end{array}$ \\
\hline \multicolumn{6}{|c|}{ N-Sowing (0 kg ha-1)/N-Topdressing (70 kg ha-1) } \\
\hline PG & $2111+94.981^{*} x-1.4221^{*} x^{2}$ & 18 & 70 & \multirow{9}{*}{33} & 3696 \\
\hline $\mathrm{MH}$ & $40.51+0.283^{\star} x-0.0041^{\star} x^{2}$ & 12 & 67 & & 45.30 \\
\hline MMG & $23.05+0.137 x-0.0026 x^{2}$ & 6 & 81 & & - \\
\hline $\mathrm{NG}>2 \mathrm{~mm}$ & $60.10-0.002 x-0.0027 x^{2}$ & 15 & 67 & & - \\
\hline ID & $0.65+0.03^{*} x-0.0004^{*} x^{2}$ & 13 & 17 & & 0.30 \\
\hline $\mathrm{Pl}$ & $786.20+44.450 * x-0.7133 * x^{2}$ & 20 & 99 & & 1480 \\
\hline PB & $104.19+0.1371^{\star} x+0.001 * x^{2}$ & 5 & 99 & & 109.80 \\
\hline FB & $107.15-0.617 x-0.0077 x^{2}$ & 7 & 76 & & - \\
\hline AM & $443.17-0.0320 x-0.0005 x^{2}$ & 3 & 85 & & - \\
\hline \multicolumn{6}{|c|}{ N-Sowing $\left(30 \mathrm{~kg} \mathrm{ha}^{-1}\right) / \mathrm{N}-$ Topdressing $\left(40 \mathrm{~kg} \mathrm{ha}^{-1}\right)$} \\
\hline$P G$ & $2340+71.980^{\star} x-1.1740^{\star} x^{2}$ & 16 & 98 & \multirow{9}{*}{30} & 3442 \\
\hline $\mathrm{MH}$ & $41.63+0.349^{\star} x-0.0058^{\star} x^{2}$ & 10 & 96 & & 46.80 \\
\hline MMG & $22.05+0.137 x-0.0024 x^{2}$ & 5 & 84 & & - \\
\hline $\mathrm{NG}>2 \mathrm{~mm}$ & $57.94-0.215 x+0.0038 x^{2}$ & 18 & 38 & & - \\
\hline ID & $0.65-0.001^{*} x+0.00001^{*} x^{2}$ & 8 & 16 & & 0.62 \\
\hline $\mathrm{Pl}$ & $894.51+19.374^{*} x-0.3183^{*} x^{2}$ & 16 & 94 & & 1189 \\
\hline PB & $103.7+0.1773^{\star} x+0.0008^{\star} x^{2}$ & 5 & 99 & & 109.74 \\
\hline FB & $132.44-0.248 x+0.0032 x^{2}$ & 4 & 95 & & - \\
\hline AM & $435.42+0.691 x-0.0116 x^{2}$ & 5 & 87 & & - \\
\hline \multicolumn{6}{|c|}{ N-Sowing $\left(60 \mathrm{~kg} \mathrm{ha}^{-1}\right) / \mathrm{N}$-topdressing $\left(10 \mathrm{~kg} \mathrm{ha}^{-1}\right)$} \\
\hline$P G$ & $3169+27.440^{\star} x-0.4538^{\star} x^{2}$ & 13 & 98 & \multirow{9}{*}{30} & 3654 \\
\hline $\mathrm{MH}$ & $42.11+0.112 x-0.0009 x^{2}$ & 9 & 75 & & - \\
\hline MMG & $23.58+0.075 x-0.0012 x^{2}$ & 8 & 85 & & - \\
\hline $\mathrm{NG}>2 \mathrm{~mm}$ & $60.55+0.021 x-0.0015 x^{2}$ & 14 & 15 & & - \\
\hline ID & $0.70-0.003^{*} x+0.00004^{*} x^{2}$ & 7 & 41 & & 0.63 \\
\hline $\mathrm{Pl}$ & $657.04+34.884^{*} x-0.5595^{*} x^{2}$ & 15 & 99 & & 1199 \\
\hline PB & $106.68+0.2303^{\star} x-0.0021^{\star} x^{2}$ & 4 & 90 & & 117.70 \\
\hline FB & $130.80-0.019 x-0.0010 x^{2}$ & 6 & 99 & & - \\
\hline AM & $439.40+0.680 x-0.0137 x^{2}$ & 6 & 74 & & - \\
\hline \multicolumn{6}{|c|}{$\begin{array}{l}\mathrm{R}^{2} \text { - Coefficient of determination; N-time - Adjusted ideal time (days after emergence); } \\
\mathrm{Y} \text { - Variable estimated for the ideal time; } \mathrm{ns},{ }^{*}-\text { Not significant, significant at } \mathrm{p} \leq 0.05 \text { by } \\
\text { the F test, respectively. PG - Grain productivity }\left(\mathrm{kg} \mathrm{ha}^{-1}\right) ; \mathrm{MH} \text { - Mass of hectoliter } \\
\left(\mathrm{kg} \mathrm{hL}^{-1}\right) ; \mathrm{MMG} \text { - Mass of one thousand grains }(\mathrm{g}) ; \mathrm{NG}>2 \mathrm{~mm}-\mathrm{Number} \text { of grains greater } \\
\text { than two millimeters }(\mathrm{n}) ; \mathrm{ID}-\text { Dehulling index }\left(\mathrm{g} \mathrm{g}^{-1}\right) ; \mathrm{PI}-\text { Industrial productivity } \\
\left(\mathrm{kg} \mathrm{h}^{-1}\right) ; \mathrm{PB}-\text { Crude protein }\left(\mathrm{g} \mathrm{kg}^{-1}\right) ; \mathrm{FB}-\text { Crude fiber }\left(\mathrm{g} \mathrm{kg}^{-1}\right) ; \mathrm{AM}-\text { Starch }\left(\mathrm{g} \mathrm{kg}^{-1}\right)\end{array}$} \\
\hline
\end{tabular}

same variables (Table 4). In this condition, the ideal time of nitrogen supply was at 30 days after emergence, with hectoliter mass expression of $46.80 \mathrm{~kg} \mathrm{hL}^{-1}$, dehulling index of $0.62 \mathrm{~g} \mathrm{g-}^{-1}$, industrial productivity of $1189 \mathrm{~kg} \mathrm{ha}^{-1}$ and crude protein with $109.74 \mathrm{~g} \mathrm{~kg}^{-1}$. The combination of $60 \mathrm{~kg} \mathrm{ha}^{-1}$ of nitrogen at sowing with $10 \mathrm{kgha}^{-1}$ in topdressing, also shows significant quadratic behavior in the same variables, except for the hectoliter mass. In this condition, the ideal time of supply was also 30 days after emergence, with an expression of dehulling index of $0.63 \mathrm{~g} \mathrm{~g}^{-1}$, industrial productivity of $1199 \mathrm{~kg} \mathrm{ha}^{-1}$ and crude protein with $111.70 \mathrm{~g} \mathrm{~kg}^{-1}$.

In Table 5, of the regression equation in the corn/oat system, the variables grain yield, hectoliter mass, industrial productivity and crude protein showed a significant quadratic behavior in the combination of absence of nitrogen at sowing with $100 \mathrm{~kg} \mathrm{ha}^{-1}$ of the nutrient in topdressing depending on the time of supply. The ideal time of supply that proved most efficient was 30 days after emergence in the expression of grain yield. In this perspective, the inclusion of 30 (days) in the $b_{i} x^{n}$ parameter of the equation of the other variables indicated a hectoliter mass with $50.40 \mathrm{~kg} \mathrm{hL}^{-1}$, industrial productivity of $1619 \mathrm{~kg} \mathrm{ha}^{-1}$ and crude protein with $108 \mathrm{~g} \mathrm{~kg}^{-1}$. In the combination of $30 \mathrm{~kg} \mathrm{ha}^{-1}$ of nitrogen at sowing with $70 \mathrm{~kg}$ $\mathrm{ha}^{-1}$ topdressing, significant quadratic behavior was observed for the same variables mentioned previously (Table 5). In this condition, the ideal nitrogen supply time was also 30 days

Table 5. Regression and estimation of the ideal nitrogen supply day in the indicators of grain yield and quality in the corn/ oat system

\begin{tabular}{|c|c|c|c|c|c|}
\hline Variable & Equalion & $\begin{array}{l}\text { CV } \\
(\%)\end{array}$ & $\mathbf{R}^{2}$ & $\begin{array}{l}\text { Ideal N-time } \\
\text { (days) }\end{array}$ & $\begin{array}{c}\mathrm{Y} \\
\text { (estimated) }\end{array}$ \\
\hline \multicolumn{6}{|c|}{ N-Sowing $\left(0 \mathrm{~kg} \mathrm{ha}^{-1}\right) / \mathrm{N}$-topdressing $\left(100 \mathrm{~kg} \mathrm{ha}^{-1}\right)$} \\
\hline$P G$ & $2256+81.0895 * x-1.3210 * x^{2}$ & 16 & 98 & \multirow{9}{*}{30} & 3449 \\
\hline $\mathrm{MH}$ & $45.10+0.409^{\star} x-0.0075^{\star} x^{2}$ & 18 & 98 & & 50.40 \\
\hline MMG & $24.99+0.024 x-0.0004 x^{2}$ & 7 & 4 & & - \\
\hline $\mathrm{NG}>2 \mathrm{~mm}$ & $58.96+0.156 x-0.0007 x^{2}$ & 20 & 55 & & - \\
\hline ID & $0.69+0.003 x-0.00006 x^{2}$ & 10 & 99 & & - \\
\hline $\mathrm{PI}$ & $925.20+44.240 * x-0.7030 * x^{2}$ & 20 & 99 & & 1619 \\
\hline PB & $111.90-0.290^{\star} x+0.0060^{\star} x^{2}$ & 7 & 61 & & 108.00 \\
\hline FB & $125.80-0.052 x+0.0022 x^{2}$ & 5 & 99 & & - \\
\hline AM & $445.30-0.189 x+0.0043 x^{2}$ & 5 & 63 & & - \\
\hline \multicolumn{6}{|c|}{ N-Sowing $\left(30 \mathrm{~kg} \mathrm{ha}^{-1}\right) / \mathrm{N}$-topdressing $\left(70 \mathrm{~kg} \mathrm{ha}^{-1}\right)$} \\
\hline$P G$ & $2089+85.85^{\star} x-1.403^{\star} x^{2}$ & 14 & 99 & \multirow{9}{*}{30} & 3401 \\
\hline $\mathrm{MH}$ & $45.77+0.265^{*} x-0.0052^{*} x^{2}$ & 8 & 87 & & 48.00 \\
\hline MMG & $23.47+0.082 x-0.0010 x^{2}$ & 4 & 59 & & - \\
\hline $\mathrm{NG}>2 \mathrm{~mm}$ & $52.19+0.258 x-0.0038 x^{2}$ & 19 & 61 & & - \\
\hline ID & $0.68+0.001 x-0.00002 x^{2}$ & 11 & 17 & & - \\
\hline $\mathrm{Pl}$ & $722.90+40.680 * x-0.6656^{\star} x^{2}$ & 17 & 90 & & 1344 \\
\hline PB & $115.70-0.295^{*} x+0.0054^{*} x^{2}$ & 7 & 77 & & 111.70 \\
\hline FB & $122.90+0.282 x-0.0052 x^{2}$ & 7 & 75 & & - \\
\hline AM & $438.20+0.700 x-0.0122 x^{2}$ & 6 & 94 & & - \\
\hline \multicolumn{6}{|c|}{ N-Sowing $\left(60 \mathrm{~kg} \mathrm{ha}^{-1}\right) / \mathrm{N}$-topdressing $\left(40 \mathrm{~kg} \mathrm{ha}^{-1}\right)$} \\
\hline$P G$ & $1359+81.242^{*} x-1.1358^{*} x^{2}$ & 15 & 92 & \multirow{9}{*}{33} & 2803 \\
\hline $\mathrm{MH}$ & $47.79-0.056 x-0.00005 x^{2}$ & 14 & 61 & & - \\
\hline MMG & $25.37-0.648 x+00008 x^{2}$ & 5 & 83 & & - \\
\hline $\mathrm{NG}>2 \mathrm{~mm}$ & $53.47+0.416 x-0.0058 x^{2}$ & 18 & 77 & & - \\
\hline ID & $0.71-0.0001 x-0.000005 x^{2}$ & 10 & 97 & & - \\
\hline $\mathrm{Pl}$ & $532.92+28.358^{*} x-0.3975^{\star} x^{2}$ & 16 & 85 & & 1036 \\
\hline PB & $110.02-0.021^{\star} x+0.0012^{\star} x^{2}$ & 6 & 96 & & 110.60 \\
\hline FB & $123.02+0.108 x-0.0012 x^{2}$ & 4 & 21 & & - \\
\hline AM & $437.6+0.8553 x-0.0163 x^{2}$ & 6 & 94 & & - \\
\hline \multicolumn{6}{|c|}{ 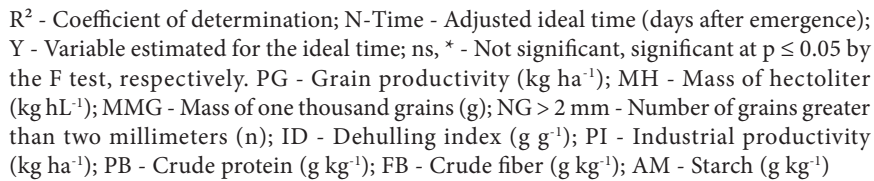 } \\
\hline
\end{tabular}


after emergence, with an estimated hectoliter mass of $48 \mathrm{~kg}$ $\mathrm{hL}^{-1}$, industrial productivity of $1344 \mathrm{~kg} \mathrm{ha}^{-1}$ and crude protein with $111.70 \mathrm{~g} \mathrm{~kg}^{-1}$. The combination of $60 \mathrm{~kg} \mathrm{ha}^{-1}$ of nitrogen at sowing with $40 \mathrm{~kg} \mathrm{ha}^{-1}$ in topdressing, indicates significant quadratic behavior for these same variables, except for the hectoliter mass (Table 5). The ideal time of supply was obtained with 33 days after emergence, with an estimated industrial productivity of $1036 \mathrm{~kg} \mathrm{ha}^{-1}$ and crude protein of $110.60 \mathrm{~g} \mathrm{~kg}^{-1}$.

In general, considering the grain and industrial productivity, the ideal time of nitrogen use in topdressing showed increased expression of variables in regression simulation compared to the intercept value $\left(b_{0}\right)$ of each equation. This occurred mainly in the absence of nitrogen at sowing and total dose applied in topdressing for the desired expectation (4000 $\left.\mathrm{kg} \mathrm{ha}^{-1}\right)$ defined in this study, regardless of the high succession system and reduced $\mathrm{N}$-residual release.

From seedling emergence to sixth leaf emission is the time when oat plants demand more nitrogen. If applied in the early stages, it favors the maximum number of spikelets and grains per panicle, when applied in the final stages, it can potentiate the number of stems per area (Arenhardt et al., 2015). In wheat, Prando et al. (2012) reported that the supply of nitrogen fertilizer at different periods of application in topdressing affected productivity, but not hectoliter mass. On the other hand, they observed that increased productivity by nitrogen doses negatively correlated to the hectoliter mass. Martins et al. (2014) found that the increase in wheat grain mass is usually associated with nitrogen availability during the flowering phase and the beginning of grain filling. Conversely, grains with higher mass do not necessarily guarantee higher productivity per area. In oats, Mantai et al. (2015) stated that the maximum efficiency of nitrogen fertilization in topdressing is obtained with total dose provided from 70 to $90 \mathrm{~kg} \mathrm{ha}^{-1}$ of nitrogen, and this variation is dependent on the condition of the agricultural year and the time of fertilization. Therefore, they reported the importance of adjusting the fertilization season with the appropriate conditions of air temperature and soil moisture. In maize, Borges et al. (2015) observed that the mass of one thousand grains was not altered by the times of nitrogen application through topdressing, a condition that was also observed in this study, involving different doses of nitrogen at sowing. In beans, Scherer et al. (2015) analyzed the effects of different nitrogen doses $\left(0,30,60\right.$ and $\left.120 \mathrm{~kg} \mathrm{ha}^{-1}\right)$ and application times (total dose at 15 days after emergence; total dose at 30 days after emergence; $50 \%$ in installments at 15 and 30 days after the emergence). The application of nitrogen in topdressing positively influenced the crop, with the total dose of $60 \mathrm{~kg} \mathrm{ha}^{-1}$ applied at 30 days after emergence but $50 \%$ installmental dose at sowing and topdressing with $120 \mathrm{~kg} \mathrm{ha}^{-1}$ showed the best results. According to Arenhardt et al. (2015), in oats the period between the beginning of tillering and elongation shows a large interval in deciding the appropriate moment of application, necessitating besides the most favorable conditions of soil moisture, other elements in dimensioning the dose and the most adjusted time of nutrient supply. According to these authors, in years favorable to cultivation, the time of fertilization with $\mathrm{N}$-fertilizer was adjusted to around 45 days after emergence and in unfavorable years to 35 days. In wheat, Alves et al. (2017) studied the interaction between Azospirillum and nitrogen doses applied by topdressing. The results showed that there was no interaction between nitrogen and inoculation. Nitrogen doses promoted significant increases in nitrogen content in leaves, plant height, number of grains per ear, number of ears per square meter and grain yield. Inoculation with Azospirillum and nitrogen doses did not promote an increase in wheat grain yield. In oats, Scremin et al. (2017) observed that the use of hydrogel increases the efficiency of nitrogen in grain yield, especially in the conditions of 30 to $60 \mathrm{~kg} \mathrm{ha}^{-1}$ of the biopolymer combined with approximately $70 \mathrm{~kg} \mathrm{ha}^{-1}$ of nitrogen in the soybean/oat system and approximately $100 \mathrm{~kg} \mathrm{ha}^{-1}$ of nitrogen in the corn/ oat system, however this effect depends on the succession system and climatic conditions.

The results presented in this study showed that the definition of nitrogen dose in sowing and the appropriate time of application, are important strategies in optimizing the nutrient to grain yield and quality with reduction of environmental impacts. This study's great contribution to the proposal to improve management technologies is highlighted, involving jointly the indicators of interest to farmers, industry and consumers, by considering the dynamics of nitrogen use and the complexity of agricultural production systems.

\section{Conclusion}

In the management of nitrogen in oats, the absence of the nutrient in sowing and application of the total dose in topdressing at 30 days after emergence provides advantageous results, improving productivity and indicators of industrial and chemical quality of the grains, regardless of the succession system.

\section{ACKNOWLEDgements}

To the Conselho Nacional de Desenvolvimento Científico e Tecnológico (CNPq), to the Coordenação de Aperfeiçoamento de Pessoal de Nível Superior (CAPES), to the Fundação de Amparo à Pesquisa do Estado do Rio Grande do Sul (FAPERGS), to the Universidade Regional do Noroeste do Estado do Rio Grande do Sul (UNIJUí) and the Instituto Federal de Educação, Ciência e Tecnologia do Rio Grande do Sul (IFRS) for the contribution of funds for the development of this study and the Scientific and Technological Initiation scholarships, Technical Support, Postgraduate and Research Productivity.

\section{Literature Cited}

Alvares, C. A.; Stape, J. L.; Sentelhas, P. C.; Gonçalves, J. L. M.; Sparovek, G. Köppen's climate classification map for Brazil. Meteorologische Zeitschrift, v.22, p.711-728, 2013. https:/doi. org/10.1127/0941-2948/2013/0507

Alves, C. J.; Arf, O.; Ramos, A. F.; Galindo, F. S.; Nogueira, L. M.; Rodrigues, R. A. F. Irrigated wheat subjected to inoculation with Azospirillum brasilense and nitrogen doses as top-dressing. Revista Brasileira de Engenharia Agrícola e Ambiental, v.21, p.537-542, 2017. https://doi.org/10.1590/1807-1929/agriambi. v21n8p537-542 
Arenhardt, E. G.; Silva, J. A. G. da; Gewehr, E.; Oliveira, A. C. de; Binelo, M. O.; Valdiero, A. C.; Gzergorczick, M. E.; Lima, A. R. C. de.The nitrogen supply in wheat cultivation dependent on weather conditions and succession system in Southern Brazil. African Journal of Agricultural Research, v.10, p.4322-4330, 2015. https://doi.org/10.5897/AJAR2015.10038

Arf, O.; Nascimento, V. do; Rodrigues, R. A. F.; Alvarez, R. de C. F; Gitti, D. de C.; Sá, M. E. de. Uso de etil-trinexapac em cultivares de arroz de terras altas. Pesquisa Agropecuária Tropical, v.42, p.150158, 2012. https://doi.org/10.1590/S1983-40632012000200008

Borges, I. D.; Pinho, R. G. V.; Pereira, J. L. de A. R.; Alvarez, C. G. D. Efeito das épocas de aplicação da cobertura nitrogenada, das fontes de nitrogênio e dos espaçamentos entre fileiras na cultura do milho. Revista Ceres, v.53, p.75-81, 2015.

Bredemeier, C.; Variani, C.; Almeida, D.; Rosa, A. T. Estimativa do potencial produtivo em trigo utilizando sensor óptico ativo para adubação nitrogenada em taxa variável. Ciência Rural, v.43, p.1147-1154, 2013. https://doi.org/10.1590/S010384782013005000080

Castro, G. S. A.; Costa, C. H. M. da; Ferrari Neto, J. Ecofisiologia da aveia branca. Scientia Agraria Paranaensis, v.11, p.1-15, 2012. https://doi.org/10.18188/1983-1471/sap.v11n3p1-15

Ercoli, L.; Masoni, A.; Pampana, S.; Mariotti, M.; Arduini, I. As durum wheat productivity is affected by nitrogen fertilization management in Central Italy. European Journal of Agronomy, v.44, p.38-45, 2013. https://doi.org/10.1016/j.eja.2012.08.005

Mantai, R. D.; Silva, J. A. G. da; Arenhardt, E. G.; Scremin, O. B.; Mamann, A. T. W. de; Frantz, R.; Valdiero, A. C.; Pretto, R.; Krysczun, D. K. Simulation of oat grain (Avena sativa) using its panicle components and nitrogen fertilizer. African Journal of Agricultural Research, v.11, p.3975-3983, 2016. https://doi. org/10.5897/AJAR2016.10943

Mantai, R. D.; Silva, J. A. G. da; Sausen, A. T. Z. R.; Costa, J. S. P.; Fernandes, S. B. V.; Ubessi, C. A eficiência na produção de biomassa e grãos de aveia pelo uso do nitrogênio. Revista Brasileira de Engenharia Agrícola e Ambiental, v.19, p.343-349, 2015. https:// doi.org/10.1590/1807-1929/agriambi.v19n4p343-349
Marolli, A.; Silva, J. A. G. da; Romitti, M. V.; Mantai, R. D.; Scremin, O. B.; Frantz, R. Z.; Sawicki, S.; Arenhardt, E. G.; Gzergorczick, M. E.; Lima, A. R. C. de.Contributive effect of growth regulator Trinexapac-Ethyl to oats yield in Brazil. African Journal of Agricultural Research, v.12, p.795-804, 2017. https://doi.org/10.5897/AJAR2016.11784

Martins, L. M.; Zagonel, J.; Ferreira, C.; Senger, M. Épocas de aplicação de regulador de crescimento e de sombreamento artificial afetando cultivares de trigo. Revista Eixo, v.3, p.47-59, 2014. https://doi. org/10.19123/eixo.v3i1.123

Prando, A. M.; Zucareli, C.; Fronza, V.; Bassoi, M. C.; Oliveira, F. A. de. Formas de ureia e doses de nitrogênio em cobertura no desempenho agronômico de genótipos de trigo. Semina: Ciências Agrárias, v.33, p.621-632, 2012. https://doi.org/10.5433/16790359.2012v33n2p621

Scherer, A. L.; Ribon, A. A.; Fernandes, K. L.; Hermógenes, V. T. L. Efeito de diferentes épocas e doses de aplicação de nitrogênio na cultura do feijoeiro cultivado em Campo Grande-MS. Revista Cultivando o Saber, v.8, p.162-171, 2015.

Scremin, O. B.; Silva, J. A. G.; Mammann, A. T. W.; Marolli, A.; Mantai, R. D.; Trautmann, A. P. B.; Kraisig, A. R.; Scremin, A. H.; Kruger, C. A. M. B.; Dornelles, E. F. Nitrogen and hydrogel combination in oat grains productivity. International Journal of Development Research, v.7, p.13896-13903, 2017.

Silva, J. A. G. da; Goi Neto, C. J.; Fernandes, S. B.V.; Mantai, R. D.; Scremin, O. B.; Pretto, R. A eficiência do nitrogênio em aveia na produtividade de grãos com estabilidade. Revista Brasileira de Engenharia Agrícola e Ambiental, v.20, p.1095-1100, 2016. https://doi.org/10.1590/1807-1929/agriambi.v20n12p1095-1100 Souza, J. L. M. de; Gerstemberger, E.; Araujo, M. A. Calibração de modelos agrometeorológicos para estimar a produtividade da cultura do trigo, considerando sistemas de manejo do solo, em Ponta Grossa-PR. Revista Brasileira de Meteorologia, v.28, p.409418, 2013. https://doi.org/10.1590/S0102-77862013000400007

Tonin, R. B.; Ranzi, C.; Camera, J. N.; Forcelini, C. A.; Reis, E. M. Amplitude térmica para germinação de conídios de Drechslera tritici-repentis. Summa Phytopathologica, v.40, p.174-177, 2014. https://doi.org/10.1590/0100-5405/1881 